\title{
Eco-Friendly Multifunctional Properties of Cochineal and Weld for Simultaneous Dyeing and Finishing of Proteinic Fabrics
}

\author{
S. M. Gawish ${ }^{1}$, R. Farouk ${ }^{2}$, A. M. Ramadan ${ }^{3}$, H. M. Mashaly ${ }^{4}$ and H. M. Helmy ${ }^{5}$ \\ National Research Center, Textile Research Division, \\ El-Behouth Street, Dokki, Giza, Egypt \\ ${ }^{1}$ samihagawish@yahoo.com \\ ${ }^{2}$ rfabdelhady@hotmail.com \\ 3ramadanam2000@yahoo.com \\ 4hamadammashaly@gmail.com \\ 5hany_helmy2001@yahoo.com
}

\begin{abstract}
Cochineal and weld natural extracts are used for eco-friendly simultaneous dyeing and finishing of silk and wool fabrics to produce functional UV protective fabrics at different dye concentrations (1 or $5 \mathrm{gm} / \mathrm{l})$ for cochineal and $(10$ or $20 \mathrm{gm} / \mathrm{l})$ for weld, dyeing is performed for the two extracts by the traditional pre-mordanting method to produce attractive brilliant red and yellow shades. The dyeing procedure is carried out at $\mathrm{pH} 4$ for both fabrics at a liquor ratio 1:40. The dyeing is started at $40^{\circ} \mathrm{C}$ and raised to $80^{\circ} \mathrm{C}$ in 30 minutes then continued for one hour. Finally, soaped using $2 \mathrm{gm} / \mathrm{L}$ (Triton $\mathrm{X}-100)$ at $500 \mathrm{C}$ for $30 \mathrm{~min}$., then rinsed and air dried. These two natural extracts have a merit of being combined between high dyeing performance and excellent UV protection properties. In addition they achieved high fastness properties. These natural colorants can be used in UV protective clothes, handmade carpets, and colored blankets.
\end{abstract}

Keywords: Cochineal, Weld, Dyeing, Mordants, UV protection

\section{INTRODUCTION}

The functional benefits of natural dyes make their utilization very important in different fields. Natural dyes were used in food coloration [1], dye sensitized solar cell [2], cosmetic products [3], water-colors, in production inks as well as textile coloration. As a result of the great challenges facing the textile finishing industry, because of the potential environmental risks from using synthetic finishing agent, in the last decade a special focus in the field of textile has been given to utilize natural dyes in textile functional finishing such as antimicrobial finishing and UV protection properties.

A. Antimicrobial finishing

Different studies are available for investigating the antimicrobial properties of natural dyes. Gupta and Bhaumik [4] have studied the treatment of cotton fabric by the tannin-rich extract of Quercus Infectoria plant using alum, copper and ferrous sulfate as mordants and then tested for antimicrobial activity against Grampositive and Gram-negative bacteria. Another study has detected the antimicrobial activity of four natural dyes (obtained from Allium cepa, Rubia tinctorum, Punica granatum L and Mentha spicata) against some pathogenic bacteria [5].

B. UV protection

UV protective properties of textiles are influenced by different factors such as fibres type, fabric construction and the nature of finishes used. In general dyed fabrics are more protective than undyed ones [6]. Different studies were investigated for determination of UV protection properties of fabrics dyed with natural dyes. Grifoni, et al., studied UV protection properties of flax and hemp dyed with some of the natural dyes, the UV transmission values of dyed fabrics were determined by in vitro testing (integrating sphere) and compared to those of outdoor assessment [7]. Different applications were investigated for using orange peel as a cheap and ready available agricultural by-product, used as natural dyestuff for dyeing wool fabrics, orange peel extracts which achieved strong and durable UV-protection properties; it was about 6 times higher than that of the wool fabric dyed with normal synthetic dyes with similar color and depth of shade [8].

\footnotetext{
*Corresponding author: Hany M. Helmy_Email: hany_helmy2001@yahoo.com Textile Research Division, National Research Centre, El-Buhouth st., Dokki, Cairo, Egypt
} 
The functionality of different kinds of natural dyes has proved the possibility of using natural dyes as a good alternative not only to synthetic dyes but also to synthetic functional finishes. In the present research, the functionality of two kinds of natural dyes, cochineal and weld extracts are studied.

Weld extract is one of the most used yellow dyes[9]. Our research applies these natural extracts on silk and wool fabrics and studies the UV protective properties of the dyed fabrics. Colour strength $(\mathrm{K} / \mathrm{S})$ and colour data $\left(L^{*}, a^{*}, b^{*}\right)$ are measured. Also, light, washing and rubbing fastness properties are assessed

\section{MATERIALS AND METHODS}

\section{A. Materials}

Cochineal and weld natural dyes were purchased from Maiwa Co., Canada.

\section{1) Chemical reagents:}

Potash alum, copper sulfate and all other chemicals and solvents used in this study were laboratory grade reagents and were purchased from local market.

\section{2) Fabrics:}

Degreased and bleached wool fabric $(308.8 \mathrm{~g} / \mathrm{m} 2,0.55 \mathrm{~mm})$, bleached silk $(58.08 \mathrm{~g} / \mathrm{m} 2,0.18 \mathrm{~mm})$ were used from local market (El-Khateib Co.). Before application, the fabrics were scoured in an aqueous solution containing $2 \mathrm{gm} / \mathrm{L}$ nonionic agent (Triton X-100) for 1 hour at $80{ }^{\circ} \mathrm{C}$ and a $50: 1$ liquor ratio, then washed thoroughly in warm water and air dried at room temperature.

\section{B. Methods}

1) Mordanting method:

In this study the simultaneous mordanting method was used during dyeing, at a liquor ratio 1:40 using 1.5 $\mathrm{gm} / \mathrm{L}$ of the following mordants.

- Potash alum, $\mathrm{Al}_{2} \mathrm{~K}_{2}\left(\mathrm{SO}_{4}\right)_{4} .24 \mathrm{H}_{2} \mathrm{O}$.

- Copper sulfate $\mathrm{CuSO}_{4}$

\section{2) Dyeing method:}

Dyeing was performed by the conventional method in an infrared dyeing machine (Roaches Co., England) at a selected dye concentration, 1 or $5 \mathrm{gm} / \mathrm{L}$ for cochineal and $10 \mathrm{or} 20 \mathrm{gm} / \mathrm{L}$ for weld. After extraction of the natural dye, a specific concentration of the dyeing bath is prepared at $\mathrm{pH} 4$ for both fabrics and at a liquor ratio 1:40. The dyeing was started at $40 \mathrm{oC}$ for 30 minutes and raised to $80 \mathrm{oC}$ and continued for one hour. Then, the fabric was soaped in a nonionic detergent $(2 \mathrm{gm} / \mathrm{L}$, Triton X-100) at $50 \mathrm{oC}$ for $30 \mathrm{~min}$., and then washed with warm water several times and air dried.

3) Measurements and testing:

1) Fastness Test:

Dyed fabrics were tested by standard ISO methods [10]. Wash fastness (ISO 105-C02 (1989)) [11] and crock fastness (ISO 105-X12 (1987)) [12] were evaluated using the visual ISO Gray Scale for both colour change (AATCC Evaluation Procedure (EP 1- similar to ISO 105-A02) and colour staining (AATCC EP 2- same as ISO 105-A03). Light fastness (Xenon arc) was evaluated using ISO 105-B02 [13].

2) Measurement of UPF factor:

The ability of the proteinic dyed fabric to block UV light is given by the ultraviolet protection factor (UPF) value. The measurement of UPF values was performed in UV/Visible Spectrophotometer 3101 PC with a software version, using an integrating sphere loaded with the fabric sample from $290 \mathrm{~nm}$ at an interval of $10 \mathrm{~nm}$.

The measurements of UV- penetration characteristics of the compressed fabric were carried out in the range of 290-400 nm using the UV penetration and protection measurement system. Before measurements the fabric was conditioned at NTP for 24 hours. During the measurements, four scans were obtained by rotating the sample $90 \mathrm{o}$ each time and the spectral data were recorded as the average of these four scans.

The equation used by the software to calculate the UPF value for a flat, tensionless dry fabric [14]:

$$
U P F=\frac{\sum_{290}^{400} E(\lambda) \times S(\lambda) \times \Delta(\lambda)}{\sum_{290}^{400} E(\lambda) \times T(\lambda) \times S(\lambda) \times \Delta(\lambda)}
$$


Where $E(\lambda)$ is the solar irradiance (Wm-2nm-1) measured; $S(\lambda)$ is the arythematic action spectrum; $\Delta(\lambda)$ is the wavelength interval of the measurements ; and $\mathrm{T}(\lambda)$ is the spectral transmittance at wavelength $\lambda 290$ $\mathrm{nm}$. The percentage blocking of UVA $(315-400 \mathrm{~nm})$ and $\operatorname{UVB}(315-290 \mathrm{~nm})$ was calculated from the transmittance data.

3) Colorimetric measurements:

The colour strength (K/S) in visible region of the spectrum (400-700) nm was calculated based on KubelkaeMunk equation:

$$
\frac{K}{S}=\frac{(1-R)_{2}}{2 R}
$$

Where, $(\mathrm{K})$ is adsorption coefficient, $(\mathrm{R})$ is reflectance of dyed sample and $(\mathrm{S})$ is scattering coefficient.

The colorimetric properties of the dyed fabrics were obtained using Ultra-scan PRO spectrophotometer (Hunter Lab, USA) under illuminant D65, $10^{\circ}$ standard observer. In terms of CIE Lab values (L*, $\left.a^{*}, b^{*}\right)$ and colour strength (K/S) [15].

\section{RESULTS AND DISCUSSION}

\section{A. Characteristics of cochineal and weld dyes}

1) Cochineal (Dactylopius Coccus costal):

Crushed cochineal female insects give a deep crimson natural dye that can be used to produce a range of scarlet, red, pink and orange shades. Carminic acid $\left(\mathrm{C}_{22} \mathrm{H}_{20} \mathrm{O}_{13}\right)$ is the main pigment of the cochineal. Carminic acid consists of a large glucose units attached by anthraquinone moiety $[16,17]$.<smiles>Cc1c(C(=O)O)c(O)cc2c1C(=O)c1c(O)c(C3O[C@H](CO)[C@@H](O)[C@H](O)[C@H]3O)c(O)c(O)c1C2=O</smiles>

Fig. 1 Chemical structure of carminic acid

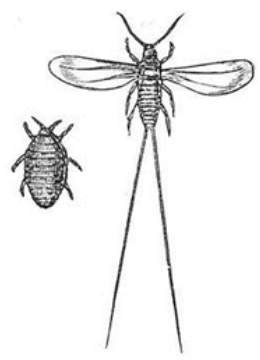

Fig. 2 Female (left) and male (right) of cochineals

The insects must be dried to about $30 \%$ of their original weight before they can be stored without decaying. The insects are processed by immersion in hot water or exposure to sunlight, steam or heated in an oven. Each method produces a different colour shade that results in the varied appearance of commercial cochineal [18].

For the preparation of carmine, the powdered insect bodies are boiled in ammonia or sodium carbonate solution. The insoluble matter is removed by filtration and alum is added to the clear solution of carminic acid to precipitate the red aluminum salt [19]. 
2) Weld (Reseda luteola):<smiles>O=c1c(O)c(-c2ccc(O)c(O)c2)oc2cc(O)cc(O)c12</smiles>

Fig. 3 Chemical structure of weld

Weld contains Luteolin and some Apigenin. Fresh leaves produce much brighter yellows than dried leaves.<smiles>O=c1cc(-c2ccc(O)cc2)oc2cc(O)cc(O)c12</smiles>

Fig. 4 Chemical structure of Apigenin

Apigenin (4, 5, 7-trihydroxyflavone), found in many plants, it is a natural product belonging to the flavone class, which is a yellow crystalline solid [20].

\section{B. Dyeing properties}

1) Effect of mordants and dye concentration on dyeing silk and wool with cochineal:

Table I shows a great deviation occurred in the $\lambda$ max of the dyed silk and wool fabrics by using $\mathrm{CuSO}_{4}$ as mordant. In case of using $1 \mathrm{~g} / \mathrm{L}$ cochineal, $\lambda \max$ decreases from $525 \mathrm{~nm}$ (control) to $360 \mathrm{~nm}$, but there is no change in case of alum which is stable at $525 \mathrm{~nm}$. On the other hand this phenomenon doesn't clearly appear in case of $5 \mathrm{gm} / \mathrm{L}$ concentration. For $1 \mathrm{gm} / \mathrm{L}$ cochineal, $\mathrm{K} / \mathrm{S}$ of the dyed silk fabric increases in the presence of $\mathrm{CuSO} 4$ compared to the control and alum mordant, also the $\mathrm{K} / \mathrm{S}$ value increases by alum compared to the control. At $5 \mathrm{gm} / \mathrm{L}$ cochineal, the silk dyed fabric, K/S increases by the presence of mordant from 1.16 (control) to 2.92 for cupper sulphate and 4.90 for alum. This means that in case of silk fabric K/S values increase in the presence of mordants. However, in $1 \mathrm{gm} / \mathrm{L}$ wool dyeing using alum $\mathrm{K} / \mathrm{S}$ decreases to 2.06 as compared to the control 5.89, while increases to 6.75 for cupper sulphate.

For $\mathrm{L}^{*}$ values (lightness), the shade of colored silk fabrics becomes darker by using $\mathrm{CuSO}_{4}$ and alum as mordants compared to the colored control fabrics. Contrary, the shade of colored wool fabrics becomes lighter by using $\mathrm{CuSO}_{4}$ and alum as mordants compared to the colored control fabrics.

Also the decrease of $a^{*}$ values and increase of $b^{*}$ values of mordanted colored silk and wool fabrics with $\mathrm{CuSO}_{4}$, means a little shift towards green co-ordinate in red yellow zone of CIE Lab color space. In the opposite, the increase of $a^{*}$ values and decrease of $b^{*}$ values of mordanted colored silk and wool fabrics with alum, means a little shift towards red co-ordinate in red blue zone of CIE Lab color space.

Mordanting generally improved dyeing performance for natural dyes, but the results show for wool dyeing with cochineal especially in high concentration $(5 \mathrm{gm} / \mathrm{l})$, that $\mathrm{K} / \mathrm{S}$ clearly decreases from 15.96 (control wool) to 4.67 (wool/ $\left.\mathrm{CuSO}_{4}\right)$ and 8.41 (wool /alum). This indicates that the dyeing of wool with cochineal is independent on mordant and can be applied without any mordant addition. 
Table I

Effect of using $\mathrm{CuSO}_{4}$ and alum as mordants on $\mathrm{K} / \mathrm{S}$, colour data and UPF of silk and wool fabrics dyed with $1 \mathrm{~g} / \mathrm{L}$ and $5 \mathrm{~g} / \mathrm{L}$ Cochineal

\begin{tabular}{|c|c|c|c|c|c|c|c|c|c|}
\hline Dye conc. & Fabric & Mordant & $\lambda_{\max }(\mathrm{nm})$ & $\mathbf{K} / \mathbf{S}$ & $\mathbf{L}^{*}$ & $a^{*}$ & $\mathbf{b}^{*}$ & UPF & UPF rating \\
\hline \multirow{6}{*}{$1 \mathrm{gm} / \mathrm{L}$} & Silk (control) & - & 525 & 0.41 & 73.38 & 8.04 & 5.03 & 16.74 & Good \\
\hline & silk & $5 \% \mathrm{CuSO}_{4}$ & 360 & 2.54 & 65.79 & 0.21 & 7.33 & 41.34 & Very good \\
\hline & silk & $5 \%$ Alum & 525 & 1.14 & 62.36 & 17.60 & -2.78 & 32.16 & Very good \\
\hline & Wool (control) & - & 525 & 5.89 & 39.06 & 23.71 & -3.42 & 294.77 & Excellent \\
\hline & wool & $5 \% \mathrm{CuSO}_{4}$ & 360 & 6.75 & 53.99 & -1.52 & 12.26 & 245.17 & Excellent \\
\hline & wool & $5 \%$ Alum & 525 & 2.06 & 52.22 & 25.43 & -3.88 & 188.43 & Excellent \\
\hline \multirow{6}{*}{$5 \mathrm{gm} / \mathrm{L}$} & Silk (control) & - & 525 & 1.16 & 65.45 & 24.33 & 2.96 & 22.90 & Good \\
\hline & silk & $5 \% \mathrm{CuSO}_{4}$ & 540 & 2.92 & 45.23 & 7.86 & 3.20 & 76.82 & Excellent \\
\hline & silk & $5 \%$ Alum & 530 & 4.90 & 47.07 & 36.96 & -4.51 & 65.78 & Excellent \\
\hline & Wool (control) & - & 530 & 15.96 & 26.5 & 25.82 & -4.06 & 534.48 & Excellent \\
\hline & wool & $5 \% \mathrm{CuSO}_{4}$ & 565 & 4.67 & 33.22 & 6.39 & 4.25 & 228.26 & Excellent \\
\hline & wool & $5 \%$ Alum & 525 & 8.41 & 36.26 & 28.08 & -5.3 & 350.6 & Excellent \\
\hline
\end{tabular}

2) Effect of mordants on weld dyed fabrics:

Table II clarifies K/S and colorimetric data results of mordanted weld dyed fabrics compared to the control dyed fabrics. $\mathrm{K} / \mathrm{S}$ increases by using mordants especially $\mathrm{CuSO}_{4}$. In case of silk dyed fabric, using $10 \mathrm{~g} / \mathrm{l}$ weld $\mathrm{K} / \mathrm{S}$ increases from 3.77 (control) to $7.78\left(\mathrm{CuSO}_{4}\right)$ and 5.03 (alum), for $20 \mathrm{~g} / 1$ weld, $\mathrm{K} / \mathrm{S}$ in presence of $\mathrm{CuSO}_{4}$ increases from 7.63 to 11.13 , on the other hand, at high concentration $(20 \mathrm{~g} / \mathrm{l})$ weld dyed wool has $\mathrm{K} / \mathrm{S}$ best result using alum (22.58) compared to $\mathrm{CuSO}_{4}$ (20.04). The control dyed fabric (18.98). At low concentration (10 $\mathrm{gm} / \mathrm{l}$ ) dyed wool mordanted with $\mathrm{CuSO}_{4}$ gives better results (14.47) compared to the control (13.03) and alum (12.8) mordanted wool fabrics, it is noticed that the control achieved better results than that of alum mordant.

From the results, it can be concluded that weld dyed silk and wool fabrics are preferable in the presence of $\mathrm{CuSO}_{4}$, at low concentration and alum at high concentration.

For L* values (lightness), the fabrics shade becomes darker by using mordants and fabrics mordanted with $\mathrm{CuSO}_{4}$ is darker than fabrics mordanted with alum and everyone of them is darker than the colored control fabrics.

Also, the decrease of $\mathrm{a}^{*}$ values and increase of $\mathrm{b}^{*}$ values of mordanted colored silk and wool fabrics with $\mathrm{CuSO}_{4}$ and alum means a little shift towards green co-ordinate in red yellow zone of CIE Lab color space. Except mordanted colored silk fabric with $\mathrm{CuSO}_{4}$, which shifted towards red co-ordinate in red yellow zone of CIE Lab color space as a result of increasing $\mathrm{a}^{*}$ and $\mathrm{b}^{*}$ values.

Table II

Effect of using $\mathrm{CuSO}_{4}$ and alum as mordants on $\mathrm{K} / \mathrm{S}$, colour data and UPF of silk and wool fabrics dyed with $10 \mathrm{~g} / \mathrm{L}$ and $20 \mathrm{~g} / \mathrm{L}$ weld

\begin{tabular}{|c|c|c|c|c|c|c|c|c|c|}
\hline Dye conc. & Fabric & Mordant & $\lambda_{\operatorname{max~nm}}$ & $\mathbf{K} / \mathbf{S}$ & $\mathbf{L}^{*}$ & $a^{*}$ & $\mathbf{b}^{*}$ & UPF & UPF rating \\
\hline \multirow{6}{*}{$\begin{array}{l}\text { Weld dye } \\
10 \mathrm{~g} / \mathrm{L}\end{array}$} & Silk (control) & - & 365 & 3.77 & 80.88 & -0.89 & 18.13 & 34.15 & Very good \\
\hline & silk & $5 \% \mathrm{CuSO}_{4}$ & 365 & 7.78 & 66.19 & 0.33 & 40.74 & 81.15 & Excellent \\
\hline & silk & $5 \%$ Alum & 365 & 5.03 & 79.14 & -2.23 & 33.20 & 53 & Excellent \\
\hline & Wool (control) & - & 365 & 13.03 & 69.63 & 0.60 & 24.80 & 349.46 & Excellent \\
\hline & wool & $5 \% \mathrm{CuSO}_{4}$ & 370 & 14.47 & 57.45 & -1.66 & 39.08 & 456. & Excellent \\
\hline & wool & $5 \%$ Alum & 370 & 12.8 & 72.6 & -3.47 & 49.96 & 212.26 & Excellent \\
\hline \multirow{6}{*}{$\begin{array}{l}\text { Weld dye } \\
20 \mathrm{gm} / \mathrm{L}\end{array}$} & Silk (control) & - & 365 & 7.63 & 75.45 & -0.58 & 20.22 & 58.11 & Excellent \\
\hline & silk & $5 \% \mathrm{CuSO}_{4}$ & 390 & 11.13 & 59.36 & 4,41 & 39.92 & 121 & Excellent \\
\hline & silk & 5\% Alum & 370 & 7.63 & 66.41 & -1.75 & 33.54 & 66.17 & Excellent \\
\hline & Wool (control) & - & 370 & 18.98 & 65.23 & 1.39 & 29.15 & 489.20 & Excellent \\
\hline & wool & $5 \% \mathrm{CuSO}_{4}$ & 375 & 20.04 & 52.30 & -2.27 & 42.04 & 348.90 & Excellent \\
\hline & wool & $5 \%$ Alum & 370 & 22.58 & 56.5 & -0.37 & 52.23 & 254.59 & Excellent \\
\hline
\end{tabular}

C. UV protective properties

1) UV protective properties of cochineal dyed fabrics: 
From Table 1 it is clear that the UPF values for dyed silk fabric ( 1 and $5 \mathrm{gm} / 1$ concentration) increased by using mordants. This indicates the important role of mordants in improving the UV protective properties of the silk fabric dyed with cochineal natural extract. The same phenomena is not appeared in case of dyeing wool with cochineal, UPF results are independent on using mordant, as they are excellent for both control and mordanted wool fabrics.

2) UV protective properties of weld dyed fabrics:

The results of Table II, demonstrates that dyeing silk with weld (10 or $20 \mathrm{gm} / \mathrm{L}$ concentration have achieved very good to excellent UPF results and the results obtained using $\mathrm{CuSO}_{4}$ mordant are the best compared to the control and alum mordanted dyed silk fabrics. But UPF values for wool dyed fabrics appear to be independent on using mordants, because UPF results are excellent for all cases for the two concentrations. However, for $20 \mathrm{gm} / 1$ concentration of the dye, UPF results of the control wool is much better than the mordanted dyed wool fabric, and in case of $10 \mathrm{gm} / 1$ the control wool is much better than wool fabric dyed using alum mordant and less than that dyed using $\mathrm{CuSO}_{4}$ mordant.

D. Fastness properties

1) The fastness properties of cochineal dyed fabrics:

The fastness properties of cochineal natural extract on silk and wool fabrics dyed at 1 or 5 gm/L concentrations using 5\%owf CuSO4 and alum mordants are illustrated in Table III compared to the control (nonmordanted) colored fabrics.

The results show that mordanting with $\mathrm{CuSO}_{4}$ improves rubbing fastness compared to the control at $1 \mathrm{gm} / \mathrm{L}$ concentration cochineal for silk dyed fabric. But in case of $5 \mathrm{gm} / \mathrm{L}$ dyed silk the rubbing fastness decreases for the mordanted fabrics compared to the control. In case of 1 or $5 \mathrm{gm} / \mathrm{L}$ wool dyed fabric the control samples have much better rubbing fastness than those for the mordanted dyed fabrics. Washing fastness for $1 \mathrm{gm} / \mathrm{l}$ silk dyed fabrics mordanted with alum is slightly better than control silk. For $1 \mathrm{gm} / \mathrm{L}$ wool dyed fabric mordanted with $\mathrm{CuSO}_{4}$, it has better washing fastness compared to the control, but in case of $5 \mathrm{gm} / \mathrm{L}$ wool dyed mordanted with alum, it shows better results compared to the control wool fabric.

At $1 \mathrm{~g} / \mathrm{L}$ dyed silk mordanted with $\mathrm{CuSO}_{4}$, it records improve for light fastness compared to both the control and that mordanted with alum. While at $5 \mathrm{~g} / \mathrm{l}$ the control sample and that mordanted with $\mathrm{CuSO}_{4}$ have higher light fastness compared to that mordanted with alum. While the light fastness for wool dyed fabrics are similar in all cases, but there is a slight increase for that mordanted with $\mathrm{CuSO}_{4}$ in case of $5 \mathrm{gm} / 1$ dye concentration.

Table III

Fastness properties of wool and silk fabrics dyed with cochineal extract.

\begin{tabular}{|c|c|c|c|c|c|c|c|}
\hline \multirow{2}{*}{ Dye conc. } & \multirow{2}{*}{ Fabric } & \multicolumn{2}{|c|}{ Fastness to rubbing } & \multicolumn{3}{|c|}{ Wash fastness } & \multirow{2}{*}{ Light } \\
\hline & & Dry & Wet & SC & SW & Alt & \\
\hline \multirow[t]{6}{*}{$1 \mathrm{gm} / \mathrm{L}$} & Control silk & 4 & 4 & $4-5$ & $4-5$ & $4-5$ & 5 \\
\hline & Silk, $5 \%$ owf $\mathrm{CuSO}_{4}$ & $4-5$ & $4-5$ & 5 & 4 & 4 & 6 \\
\hline & Silk, 5\% owf Alum. & 4 & $3-4$ & 5 & 5 & $3-4$ & $4-5$ \\
\hline & Control wool & $4-5$ & 4 & 4 & 4 & $4-5$ & 4 \\
\hline & Wool, $5 \%$ owf $\mathrm{CuSO}_{4}$ & 4 & $3-4$ & 5 & 4 & 4 & 4 \\
\hline & Wool, 5\% owf Alum. & $2-3$ & $2-3$ & 4 & $4-5$ & $2-3$ & 4 \\
\hline \multirow[t]{6}{*}{$5 \mathrm{gm} / \mathrm{L}$} & Control silk & 4 & 4 & $4-5$ & $4-5$ & $1-2$ & 6 \\
\hline & Silk, $5 \%$ owf $\mathrm{CuSO}_{4}$ & $3-4$ & 3 & $3-4$ & $4-5$ & $3-4$ & 6 \\
\hline & Silk, 5\% owf Alum & $2-3$ & $2-3$ & $4-5$ & $4-5$ & 4 & 5 \\
\hline & Control wool & $4-5$ & 4 & 3 & 3 & $3-4$ & 5 \\
\hline & Wool, $5 \%$ owf $\mathrm{CuSO}_{4}$ & 3 & $2-3$ & 4 & $3-4$ & $4-5$ & $5-6$ \\
\hline & Wool, 5\% owf Alum & 2 & $1-2$ & 4 & 4 & 4 & 5 \\
\hline
\end{tabular}

2) Fastness properties of weld dyed fabrics:

The fastness properties of dyed silk and wool fabrics with weld natural extract at 10 or $20 \mathrm{~g} / \mathrm{L}$ using $5 \%$ owf $\mathrm{CuSO}_{4}$ and alum as mordants are illustrated in Table IV compared to the control (non-mordanted) dyed fabrics.

The results clearly show that the rubbing fastness for the control silk and wool fabrics is better than the mordanted dyed fabrics for both concentrations. But washing fastness of the mordanted dyed silk and wool fabrics are slightly better than the control dyed fabrics. 
The results also indicate that the light fastness for the control silk and that mordanted with alum at both concentration (10 or $20 \mathrm{~g} / \mathrm{l})$ are higher than that mordanted with $\mathrm{CuSO}_{4}$. This is in agreement with the light fastness results of the wool dyed at low concentration. Also the result shows that the light fastness of the control is better than that mordanted with alum, but in case of high concentration, the control wool and that mordanted with $\mathrm{CuSO}_{4}$ are similar and better than that of wool mordanted with alum.

Table IV

Fastness properties of wool and silk fabrics dyed with weld extract.

\begin{tabular}{|c|c|c|c|c|c|c|c|}
\hline \multirow{2}{*}{$\begin{array}{l}\text { Dye } \\
\text { conc. }\end{array}$} & \multirow{2}{*}{ Fabric } & \multicolumn{2}{|c|}{ Fastness to rubbing } & \multicolumn{3}{|c|}{ Wash fastness } & \multirow{2}{*}{$\begin{array}{l}\text { Light } \\
\text { fastness }\end{array}$} \\
\hline & & Dry & Wet & SC & SW & Alt & \\
\hline \multirow{6}{*}{$\begin{array}{c}10 \\
\mathrm{gm} / \mathrm{L}\end{array}$} & Control silk & 5 & 5 & 4 & $3-4$ & $4-5$ & 6 \\
\hline & Silk, $5 \%$ owf $\mathrm{CuSO}_{4}$ & 4 & 4 & 4 & 4 & $4-5$ & $5-6$ \\
\hline & Silk, 5\% owf Alum. & 4 & 4 & $4-5$ & 4 & 4 & 6 \\
\hline & Control wool & $4-5$ & 4 & 4 & $3-4$ & $4-5$ & 6 \\
\hline & Wool, $5 \%$ owf $\mathrm{CuSO}_{4}$ & $3-4$ & 3 & $4-5$ & 4 & $4-5$ & $4-5$ \\
\hline & Wool, 5\% owf Alum. & 4 & $3-4$ & $4-5$ & 4 & $4-5$ & 5 \\
\hline \multirow{6}{*}{$\begin{array}{c}20 \\
\mathrm{gm} / \mathrm{L}\end{array}$} & Control silk & 4 & 4 & 4 & $3-4$ & $3-4$ & 6 \\
\hline & silk, $5 \%$ owf $\mathrm{CuSO}_{4}$ & 3 & 3 & 4 & 4 & $4-5$ & 5 \\
\hline & Silk, $5 \%$ owf Alum & $3-4$ & $3-4$ & 4 & $3-4$ & $4-5$ & 6 \\
\hline & Control wool & 4 & $3-4$ & $3-4$ & $3-4$ & 4 & 6 \\
\hline & wool, $5 \%$ owf $\mathrm{CuSO}_{4}$ & 4 & $2-3$ & $4-5$ & $3-4$ & 4 & 6 \\
\hline & Wool, $5 \%$ owf Alum & 3 & 3 & 4 & $3-4$ & $4-5$ & $5-6$ \\
\hline
\end{tabular}

\section{CONCLUSION}

The present study investigates coloration and UV protection functional properties of cochineal and weld natural extracts on silk and wool fabrics. The natural dyes used achieved bright red and/or yellow colors with high K/S values and excellent UV protection properties. In addition to the excellent results obtained, it was observed the capability of dyeing wool fabric with cochineal without using any mordant, without affecting the dyed wool functional or coloration properties. We can say that cochineal and weld dyes are good alternative not only to synthetic dyes but also to synthetic UV functional finishes for wool and silk fabrics.

\section{ACKNOWLEDGMENT}

The authors gratefully acknowledge the support of project no 9163 (2014), awarded by Scientific Technology and Development funds (STDF) - "Academy of Scientific Research and Technology", Egypt.

\section{REFERENCES}

[1] F. Delgado-Vargas, A.R. Jimenez, O. Paredes-Lopez, Natural pigments: carotenoids, anthocyanins, and betalains d characteristics, biosynthesis, processing, and stability. Crit., Crit. Rev. Food Sci. Nutr., Vol. 40,PP. 173-289, 2000.

[2] S. Hao, J. Wu, Y. Huang, J. Lin, Natural dyes as photosensitizers for dyesensitized solar cell., Sol. Energ., Vol. 80,PP. 209-214, 2006.

[3] A.C. Dweck, Natural ingredients for colouring and styling. Int. , J. Cosmet. Sci. , Vol. 24,PP. 287-302, 2202.

[4] D. Gupta, S. Bhaumik, Antimicrobial treatments for textiles., J. Fibre Text. Res. , Vol. 32,PP. 254-263, 2007.

[5] A. Calis, G.Y. Celik, H. Katircioglu, Antimicrobial effect of natural dyes on some pathogenic bacteria. , Afr. J. Biotechnol. , Vol. 8,PP. 291-293, 2009.

[6] Hustvedt G. , C.P. C., Textile technology: The Ultraviolet Protection Factor of Naturally-pigmented Cotton, J Cotton Sci, Vol. 9,PP. 47-55, 2005.

[7] D. Grifoni, L. Bacci, G. Zipoli, G. Carreras, S. Baronti, F. Sabatini, Laboratory and outdoor assessment of UV protection offered by flax and hemp fabrics dyed with natural dyes, Photochemistry and Photobiology,, Vol. 85,PP. 313-320, 2009.

[8] X. Hou, X. Chen, Y. Cheng, H. Xu, L. Chen, Y. Yang, Dyeing and UV-protection properties of water extracts from orange peel, J Clean Prod, Vol. 52,PP. 410-419, 2013.

[9] M. Mirjalili, K. Nazarpoor, L. Karimi, Eco-friendly dyeing of wool using natural dye from weld as co-partner with synthetic dye, J Clean Prod, Vol. 19,PP. 1045-1051, 2011.

[10] ISO, Methods of tests for color fastness of textiles and leather, , 5th ed, Society of Dyers and Colourists Bradford., 1990.

[11] ISO, Textiles: Tests for colour fastness:, Colour Fastness to washing:105-C01:1989(E) Basel, Switzerland, 1989.

[12] ISO, Textiles: Tests for colour fastness: , Colour fastness to rubbing test: ISO 105-B02: 1988 Basel, switzerland, 1987.

[13] ISO, Textiles:Tests for colour fastness:, Colour fastness to artificial light: Xenon arc fading lamp: ISO 105-B02: 1988Basel, switzerland, 1988. 
[14] Gawish S. , R.A. . Effect of Nano Zinc Oxide onto Polypropylene Properties Yarns I-UV Protective Polypropylene/Nano Zinc Oxide Yarns Using Compounding Melt Extrusion and Spinning Technique. , International Journal of Textile Science., Vol. 2,PP. 121-125, 2013.

[15] L.J. Rather, S.U. Islam, M. Azam, M. Shabbir, M.N. Bukhari, M. Shahid, M.A. Khan, Q.M.R. Haque, F. Mohammad, Antimicrobial and fluorescence finishing of woolen yarn with Terminalia arjuna natural dye as an ecofriendly substitute to synthetic antibacterial agents., RSC Advances, Vol. 6,PP. 39080-39094, 2016.

[16] A.G. Lloyd, Extraction and chemistry of cochineal, Food Chemistry, Vol. 5,PP. 91-107, 1980.

[17] A. Chieli, J. Sanyova, B. Doherty, B.G. Brunetti, C. Miliani, Chromatographic and spectroscopic identification and recognition of ammoniacal cochineal dyes and pigments, Spectrochimica Acta Part A: Molecular and Biomolecular Spectroscopy, Vol. 162,PP. 86$92,2016$.

[18] A. Serrano, A. van den Doel, M. van Bommel, J. Hallett, I. Joosten, K.J. van den Berg, Investigation of crimson-dyed fibres for a new approach on the characterization of cochineal and kermes dyes in historical textiles, Analytica Chimica Acta, Vol. 897,PP. 116-127, 2015.

[19] M.E. Borges, R.L. Tejera, L. Díaz, P. Esparza, E. Ibáñez, Natural dyes extraction from cochineal (Dactylopius coccus). New extraction methods, Food Chemistry, Vol. 132,PP. 1855-1860, 2012.

[20] M. Mirjalili, K. Nazarpoor, L. Karimi, Eco-friendly dyeing of wool using natural dye from weld as co-partner with synthetic dye, Journal of Cleaner Production, Vol. 19,PP. 1045-1051, 2011.

\section{AUTHOR PROFILE}

Prof. Dr. Samiha Gawish was born in 27 February 1945. She earned a B.Sc. from faculty of Engineering in 1968 and a M.Sc. in 1975 at Alexandria University. She then received her Ph.D. in 1980. Her main field is Textile Chemistry \& Technology. She was a professor at National Research Centre from 1990 to 2005. Since 2005 she has been an emeritus Professor at NRC.

Dr. Reham Farouk was born in 23 July 1976. She earned a B.Sc. from faculty of Applied Arts in 2000 and a M.Sc. in 2003 at Helwan University. She then received her Ph.D. of Applied Arts in 2007. Her main field is textile dyeing technology. She has been an associate professor at National Research Centre from 2012 till now.

Prof. Dr. Amira Ramadan was born in 4 February 1956. She earned a B.Sc. from faculty of Science in 1978 and a M.Sc. in 1988 at Cairo University. She then received her Ph.D. in Organic Chemistry in 1995. Her main field is textile chemistry. She has been a professor at National Research Centre from 2005 till now.

Prof. Dr. Hamada Mashaly was born in 23 December 1969. He earned a B.Sc. from faculty of Science in 1991 at Mansoura University and a M.Sc. in Organic Chemistry in 2000 at Zagazik University. He then received his Ph.D. in 2005 from Ain Shams University. His main field is dyes and textile dyeing Chemistry. He has been a professor at National Research Centre from 2015 till now.

Dr. Hany Helmy was born in 29 January 1970. He earned a B.Sc. from faculty of Applied Arts in 1992 and a M.Sc. in 1998 at Helwan University. He then received his Ph.D. of Applied Arts in 2004. His main field is textile dyeing technology. He has been an associate professor at National Research Centre from 2010 till now. 